\title{
Experimental study of the performance of an earth to air heat exchanger located in arid zone during the summer period
}

Omar Hamdi*, Abdelhafid Brima, Nouredine Moummi, Hamza Nebbar

Mechanical Engineering Laboratory (L.G.M), Department of Mechanical Engineering. Biskra University, Algeria

Corresponding Author Email: ilmomar@gmail.com

https://doi.org/10.18280/ijht.360422

Received: 18 July 2017

Accepted: 28 April 2018

\section{Keywords:}

air-ground heat exchange, buried pipe, energy performance, soil temperature

\begin{abstract}
The aim of this study is to explore the performance of an Earth to Air Heat Exchanger (EAHE) and find out the utility of the device in the cooling of buildings in the hot region. The EAHE cooling potential was experimentally investigated for a placement in Biskra, a city located in the south east of Algeria. A cylindrical tube of PVC in the serpentine form having an internal diameter of $0.110 \mathrm{~m}$ and a total length of $56 \mathrm{~m}$ is buried at $3 \mathrm{~m}$ depth with a slope of $2 \%$ at Biskra University. The temperature readings of soil, external air and a buried duct at several positions were recorded during the period of May and September of the year 2013. Results showed that EAHE cooling potential (discrepancy between the inlet temperature (ambient) and the outlet temperature of the EAHE) was found promising as it could exceed $15^{\circ} \mathrm{C}$. The duration of operation of the heat exchanger does not influence the outlet temperature. EAHE is very useful to refresh buildings during spring and early summer, but it can just be used for pre-cooling in the rest of summer and autumn seasons. Moreover, a database was developed about the temperatures of the soil, external air and at the outlet of the device which may be useful for researchers in the future.
\end{abstract}

\section{INTRODUCTION}

During the last two decades, the use of air conditioning during summer has considerably increased in southern Algerian cities in particular as the hot period is relatively long: it begins in May and runs until October in Biskra for instance where our experiment was carried out. This caused several electrical overloads and cuts. Given that an airconditioned building consumes around 2 to 3 times the energy consumed by the building without air conditioning [1]. In addition, electricity in Algeria is $100 \%$ fossil, the implementation of a renewable alternative to conventional air conditioning or at least reduces its energy consumption deems to be necessary. The Earth to Air Heat Exchanger (EAHE) is one of the very few energy consuming systems used in heating/cooling Buildings. It exploits like any geothermal system, soil thermal inertia. Its simple principle consists of an air intake from the atmosphere and flows through a buried pipe to the building to refresh. In winter, the air is pre-heated because the ground is warmer than the air outside. In summer, the air is cooled as it is the opposite phenomenon that occurs [2-3]. This is due to the fact that the soil temperature remains constant beyond a certain depth: 2.5-3m [4]. This type of installation has existed for millennia (3000 b c.) [4], but the first studies began to appear in the mid-twentieth century. After the oil shock of 1979, research on air-ground heat exchangers EAHEs has grown especially during the last three decades [5]. Peretti et al. [3] presented a synthesis study of works done in this theme before 2013. The authors have shown all theoretical and numerical modeling of heat and mass transfer in an EAHE with their inputs and outputs. They also discussed the software designed for calculation and design of EAHEs. They ended up describing the various hybrid ventilation systems with which was coupled an EAHE and the different types of buildings where these systems were applied. In arid areas, several studies have been made. F. Al-Ajmi et al. [6] developed a theoretical model to predict an EAHE air outlet temperature and the potential of this cooling device in a hot and arid climate. The model was coded for a typical home of Kuwait City, in TRNSYS-IISIBAT environment. They showed that the EAHE had the potential to reduce home cooling energy demand by $30 \%$ during the summer season. In two different studies, V. Bansal et al. [7-8] performed a numerical simulation of thermal performance and cooling capacity of an EAHE in hot and arid conditions. They have shown that the performance of the EAHE is not significantly affected by the material of the buried pipe, while the air velocity through the buried pipe has been found significantly affecting the performance of the EAHE. Then, they incorporated an evaporative cooler to the output of an EAHE. By numerical modeling adapted to hot and dry climatic conditions, it has been shown that there is a significant improvement in the utility of EATHE system when integrated with an evaporative cooler. Alghannam [9] examined the Coefficient of Performance (COP) of the EAHE for sandy soil in a hot and arid climate. They found experimentally that the average COP is 6.32 during the heating tests and 1.75 during the cooling tests. R. Misra et al. evaluated the thermal performance of an EAHE operating under transient conditions primarily to a hot and arid climate [10]. Using a numerical modeling and experimental measurements, the authors have shown that the transient thermal performance of an EAHE is substantially dependent on the thermal conductivity of the soil and the length of its continuous operation. N. Moummi et al. [11] conducted a theoretical 
modeling study of an EAHE. The exposed analytical model reflects changes in the air temperature at the outlet of EAHE according to the main parameters such as the thermo physical characteristics of the soil, the climatic conditions, the tube size (inside diameter and length), air flow... etc. In order to improve the energy yield of EAHEs, K. Dehina and AM Mokhtari [12] proposed a numerical simulation of a heat exchanger air-ground-water in co-current. They incorporated a coaxial tube of smaller section transporting irrigation water supposed at constant temperature. The authors conducted a comparative study between the energy gain that we could have in the case of an EAHE and the case of ground-waterair heat exchanger with respect to mechanical ventilation by direct extraction from the outside air. They concluded that the soil-water-air exchanger is much more effective than a simple EAHE if the transported fluid has interesting thermal characteristics. Sehli et al. [13] have proposed a onedimensional numerical model to estimate the performance of EAHEs installed at different depths, used for heating or cooling the premises. The authors eventually deduced that EAHE cannot ensure thermal comfort inside homes in southern Algeria. Mebarki et al. [14] undertook a study of the performance of an EAHE by an analytical modeling. They analyzed the influence of some parameters, namely: the depth, the diameter and the length of the tube on the internal temperature of the heat exchanger. They have concluded that sandy soil is more inert than other types of simulated ground and therefore much more efficient in terms of heat exchange, as it allows getting closer to the soil temperature. $M$. Benhammou and B. Draoui [15] conducted a theoretical study on geothermal exchanger of air aimed for cold production. The study is done to the climatic conditions of southern Algeria. The results obtained indicate that this technique is promising and can be substituted for conventional air conditioning. Y. Belloufi et al. [16] presented an experimental and numerical study of the air cooling using EAHE. To determine temperature distribution along the pipe, the authors proposed a transient onedimensional numerical model using finite differences method. The numerical model results were compared with experimental measurements and a good agreement was found. They deduced that the exploitation of EAHE alone cannot give the thermal comfort of cooling. Consequently, it can reduce the electric power consumption like using the means of air conditioning. A. Rouag et al. [17] designed an earthwater heat exchanger to use it as a supplementary water cooling system of the solar adsorption air refreshment systems in the region of Biskra (Algeria). Results are very significant and showed that the geothermal solution can effectively replace the dry cooling tower and presents an important reduced cost compared with other solutions.

In this present study, experimental measurements performed on an EAHE implanted at the University of Biskra will exposed. The city of Biskra $\left(35^{\circ} 33{ }^{\prime} \mathrm{N}\right.$ and $\left.6^{\circ} 11^{\prime} \mathrm{E}\right)$ is characterized in summer by a hot and dry climate, the average temperature is about $40{ }^{\circ} \mathrm{C}$. The measurements were taken during a period from the beginning of May until 19 September 2013. A brief analysis of the encouraging results made us optimistic about the future of this technology in southern Algeria.

\section{EXPERIMENTATION}

\subsection{Site features}

Biskra $\left(34^{\circ} 51^{\prime} 00\right.$ "N $\left.5^{\circ} 44^{\prime} 00^{\prime \prime} \mathrm{E}\right)$ is a city located in north of the Sahara, in the foothills of the Aures and Zab Mountains, $400 \mathrm{~km}$ south-east of Algiers, capital of Algeria. The climatic characteristics of Biskra city are presented in the Table 1 [18].

Table 1. Meteorological data for the city of Biskra

\begin{tabular}{|ccccccc|}
\hline Month & Jan & Fe & Mar & Apr & May & Jun \\
\hline $\operatorname{Tav}\left({ }^{\circ} \mathbf{c}\right)$ & 11.9 & 13.7 & 16.2 & 20.0 & 25.2 & 29.9 \\
\hline $\operatorname{Hav}(\%)$ & 57 & 52 & 44 & 40 & 37 & 31 \\
\hline $\operatorname{Vav}(\mathbf{m} / \mathbf{s})$ & 3.70 & 4.18 & 4.59 & 4.82 & 4.78 & 4.34 \\
\hline $\operatorname{Rav}\left(\mathbf{w} / \mathbf{m}^{2}\right)$ & 211.7 & 295.5 & 411.7 & 489.7 & 511.2 & 533.5 \\
\hline $\operatorname{Month}$ & Jul & Aug & Sep & Oct & Nov & Dec \\
\hline $\operatorname{Tav}\left({ }^{\circ} \mathbf{c}\right)$ & 33.5 & 32.7 & 27.5 & 22.1 & 16.5 & 12.8 \\
\hline $\operatorname{Hav}(\%)$ & 29 & 31 & 40 & 49 & 57 & 60 \\
\hline $\operatorname{Vav}(\mathbf{m} / \mathbf{s})$ & 3.70 & 3.82 & 3.58 & 3.82 & 3.60 & 3.65 \\
\hline $\operatorname{Rav}\left(\mathbf{w} / \mathbf{m}^{\mathbf{2}}\right)$ & 525.1 & 476 & 398.8 & 304.2 & 219.2 & 177.7 \\
\hline
\end{tabular}

With Tav, Hav, Vav and Rav are means of ambient temperature, relative humidity, wind speed and solar radiation respectively.

The site's soil is Silt clay-sandy by nature and its thermo physical properties are given in the Table 2 [18].

Table 2. Thermo physical properties of soil of the site

\begin{tabular}{|c|c|c|c|c|}
\hline $\begin{array}{c}\text { Density } \\
\rho\left(\mathrm{kg} / \mathrm{m}^{3}\right)\end{array}$ & $\begin{array}{c}\text { Calorific } \\
\text { capacity } \\
\text { C(J/kg.K) }\end{array}$ & $\begin{array}{c}\text { Thermal } \\
\text { conductivity } \\
\lambda(\mathrm{w} . \mathrm{m} / \mathrm{K})\end{array}$ & $\begin{array}{c}\text { Thermal } \\
\text { diffusivitya } \\
\left(\mathrm{m}^{2} / \mathrm{s}\right)\end{array}$ & $\begin{array}{c}\text { Penetration } \\
\text { depth } \\
\delta(\mathrm{m})\end{array}$ \\
\hline 1800 & 1340 & 1.5 & $6.22 \times 10-7$ & 2.5 \\
\hline
\end{tabular}

\subsection{Soil temperature}

Soil temperature is an important parameter in solar and geothermal energy applications such as passive heating and cooling of buildings and greenhouses [19-20]. The soil temperature depends on the depth at which that temperature is measured and site weather such as solar radiation, ambient temperature and wind speed. It also depends on the type of soil and environmental surroundings of the site as an example the presence of a building in the vicinity [21].

Soil temperature of the site at a depth of $3 \mathrm{~m}$ during the test period is shown in curve of Figure 1.

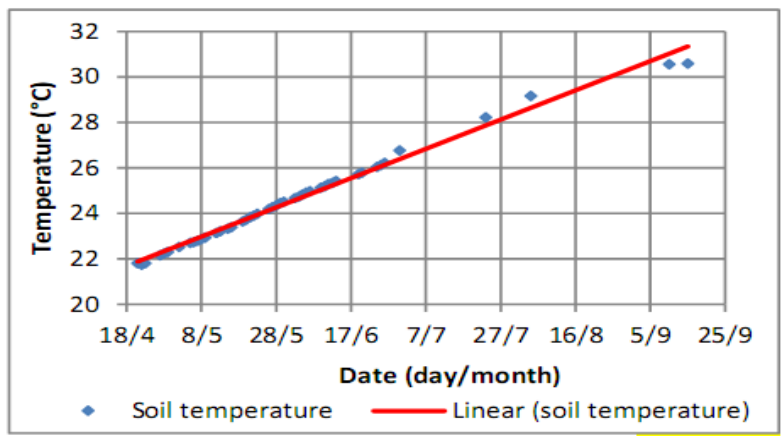

Figure 1. Soil temperature variation at $3 \mathrm{~m}$ depth within hot specified period 


\subsection{Earth air heat exchanger}

The experimental device, as shown in photo of Figure 2 and diagram of Figure 3, is a cylindrical tube of PVC, consisting of four sections connected one to another to form a coil. The tube is an inner diameter of about $0.110 \mathrm{~m}$ and a total length about $56 \mathrm{~m}$. It is buried at a depth of $3 \mathrm{~m}$ with a slope of $2 \%$. The sections are disposed and spaced each other by a distance between axes of $2 \mathrm{~m}$. The ends were connected to two vertical sections to allow air to enter the tube and get out of the latter. Ambient air is blown inside the tube using an S\&P TD-800 fan, power of $120 \mathrm{~W}$. Its speed of rotation is adjustable, which allowed us to control the speed and the air flow through the exchanger. Probes (P1, P2.., Pi..., P17) were placed at various locations along the pipe buried to measure air temperature inside the tube to various distances from the entrance. These distances (in meters) are illustrated in Table 3. The air enters the tube at a temperature equal to the ambient temperature; it flows into the buried tube and loses heat progressively along the tube to exit it at a moderate temperature.

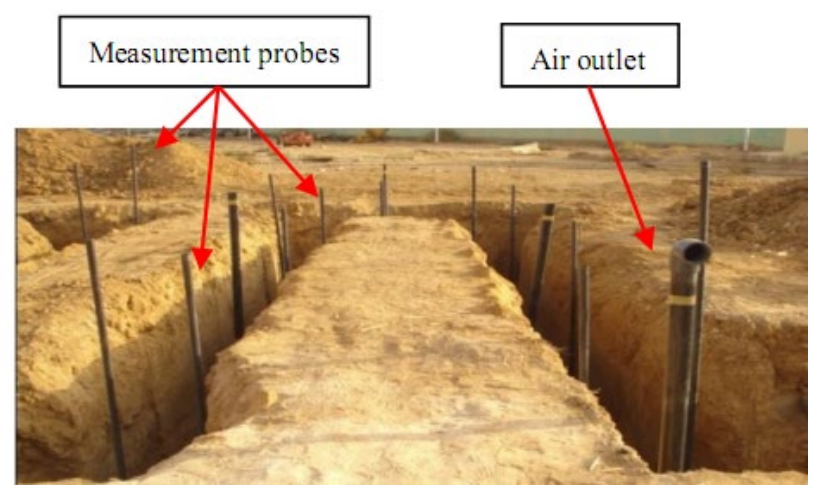

Figure 2. Field heat exchanger installation

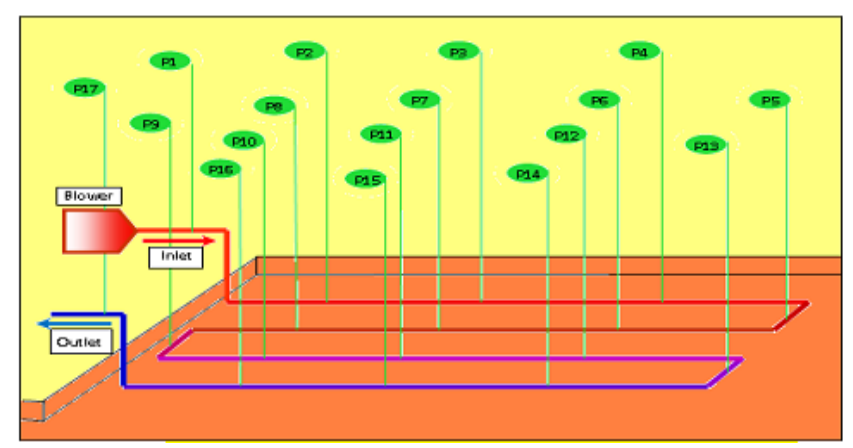

Figure 3. Buried pipe temperature measuring probes spray

Table 3. Locations distances of the probes

\begin{tabular}{|c|c|c|c|c|c|c|}
\hline Probes & $\mathrm{P} 1$ & $\mathrm{P} 2$ & P3 & P4 & P5 & P6 \\
\hline Distance & 0.000 & 3.630 & 7.690 & 13.885 & 16.035 & 20.070 \\
\hline Probes & P7 & P8 & P9 & P10 & P11 & $\mathrm{P} 12$ \\
\hline Distance & 24.120 & 26.370 & 29.065 & 33.095 & 37.005 & 38.885 \\
\hline Probes & P13 & P14 & P15 & P16 & P17 & \\
\hline Distance & 0.815 & 45.100 & 48.800 & 53.160 & 56.790 & \\
\hline
\end{tabular}

The acquisition of measurements (temperature) is done using a DAQ-9188 acquisition card (National Instruments), see Figure 4., which transmits the values read by the temperature sensors to a PC where they are processed and stored by appropriate software (LabVIEW SignalExpress, V
5.0), Figure 5.

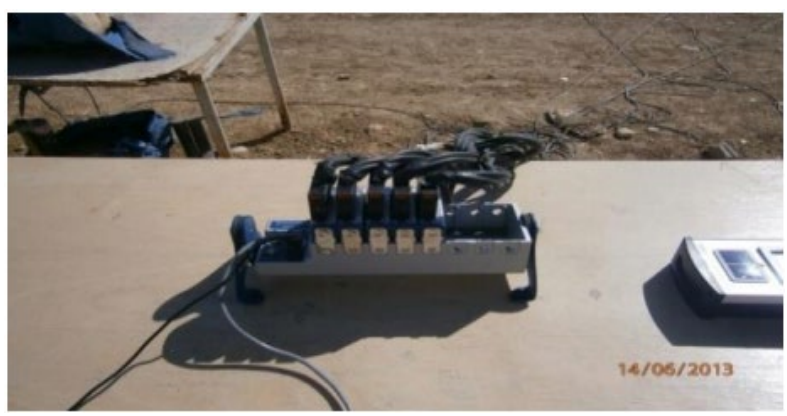

Figure 4. DAQ-9188 acquisition card (National Instruments)

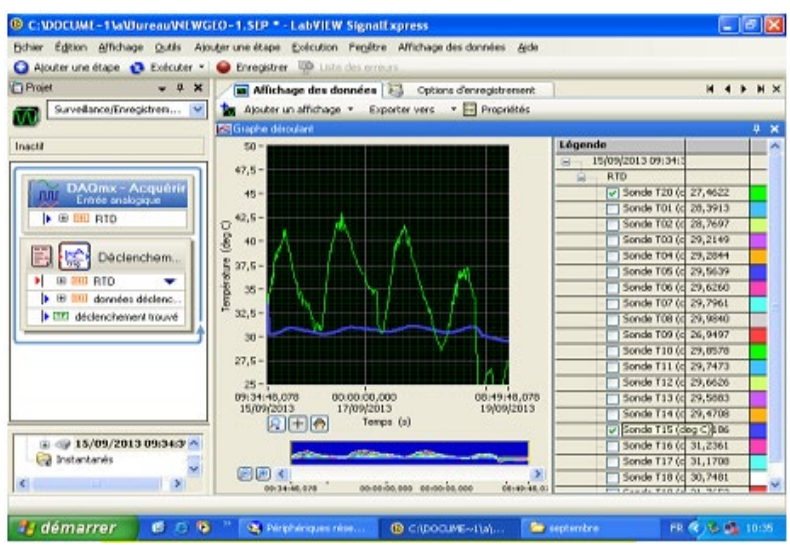

Figure 5. Inlet and outlet temperatures displayed by LabVIEW SignalExpress V 5.0

Measurements were recorded for every 15 minutes, from 08:00 to 17:00, during the period beginning May 2, 2013 and were extended until September 19 of the same year. It was also made a series of measurements continuously for 24,48 , 72 and 96 hours non-stop, day and night.

\section{RESULTS AND DISCUSSION}

The experiments have allowed us to see good differences between the air temperature at the inlet and outlet of the heat exchanger. These temperature differences, which reflect the cooling potential of the exchanger, can be up to $18{ }^{\circ} \mathrm{C}$ when ambient temperatures (at the entrance of the heat exchanger) are very high in the range of $49{ }^{\circ} \mathrm{C}$ Fig 6 . This is very important with regard to the region during the hot summer period. In fact, to reach the comfort temperature (25-28), it would be more economical to use EAHE for a pre-cooling (decrease the temperature from more than $40-45^{\circ} \mathrm{C}$ to an intermediate temperature). Then and using a conventional air conditioner, the temperature continues to be lowered to reach the range of comfort, as is the case of September Figure 6 and Figure 7. Air conditioners may even not be needed since the comfort temperature can be achieved using EAHE alone as in the case of May 27, Figure 7. It only remains to check also the effect of the difference between the air temperature at the exit of the EAHE and the temperature inside the building to refresh. As in the case of cooling by ventilation, the air flow required is proportional to the temperature difference [22]. Air temperature at the outlet of exchanger is about $24{ }^{\circ} \mathrm{C}$ at the beginning of May and reaches about $30{ }^{\circ} \mathrm{C}$ at the beginning of September Figure 6 . This increase is due 
to a rising of the soil temperature resulted from the warming ground during the season of summer caused by solar radiations [21]. This causes the elevation of the ground temperature Figure 1.

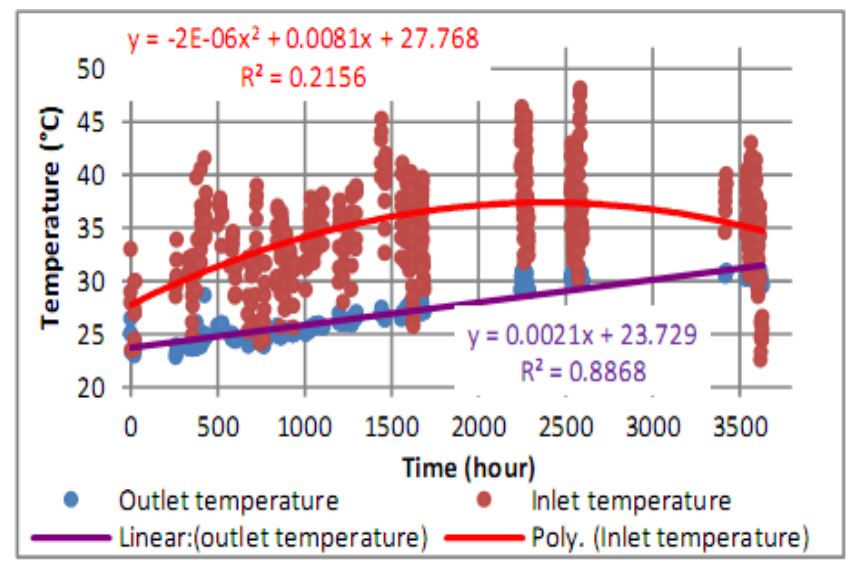

Figure 6. Air temperature at the inlet and outlet of the exchanger

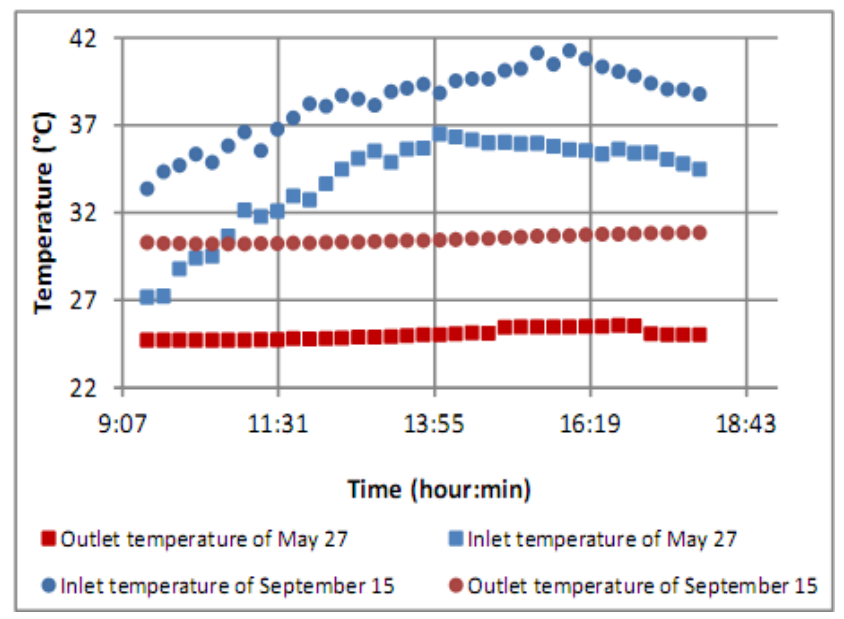

Figure 7. Heat exchanger inlet and outlet temperatures of two days

The curve in Figure 8 shows the variation of the air temperature inside the buried pipe as a function of the length of the pipe during five hours of operation of the exchanger. It is clear that the air temperature decreases to a considerable extent by increasing the length of the exchanger to approximately $35 \mathrm{~m}$. Beyond this length, the temperature of the air inside the tube tends to be constant even with increasing the length of the exchanger. Therefore, the buried tube length should be optimized by taking account of this finding in the design. The air temperature increase at the end of the exchanger between the abscissas $48.800 \mathrm{~m}$ and 53.160 $\mathrm{m}$ is due to the vertical portion of the tube which ascends to the surface because the soil temperature around this portion of the tube increases progressively upward at the ground surface. It is also due to a part of this portion which is situated above the ground surface and subsequently subjected to ambient air temperature. This problem can be solved, in existing installations, by performing good thermal insulation of the vertical portion at the end of the heat exchanger, or by placing this section directly under the building to refresh immune to ambient air. It is also observed that the temperature inside the buried pipe decreases with the elevation of the heat exchanger operating time from the beginning of the tube up to $40 \mathrm{~m}$ away, but beyond $45 \mathrm{~m}$ the temperature remains almost constant advancing in time. This shows that a good sizing of buried pipe is necessary to ensure an acceptable outlet temperature and avoid over sizing and minimize pressure drops

Another remarkable result is that it can be drawn from the curve of Figure 9. The thermal performances are not affected after a relatively long operating time. After a 96-hour period of continuous operation of the exchanger, day and night, the air temperature at the outlet of the exchanger and / or the temperature difference between the inlet and the outlet of the air of the heat exchanger does not depend on the duration of operation. This is a very important parameter and encouraging factor for the use of this type of installation to refresh residential buildings or offices. This is valid for relatively short periods of a few days, but if the entire period of summer is taken into accounts, the ground temperature increases by $24^{\circ} \mathrm{C}$ at the end of April and early May to reach $32{ }^{\circ} \mathrm{C}$ in September figure 6 . This increase resulted directly in an increase in the EAHE outlet air temperature. The decrease in the temperature difference between the inlet and the outlet of the exchanger is due solely to the decrease of the ambient temperature.

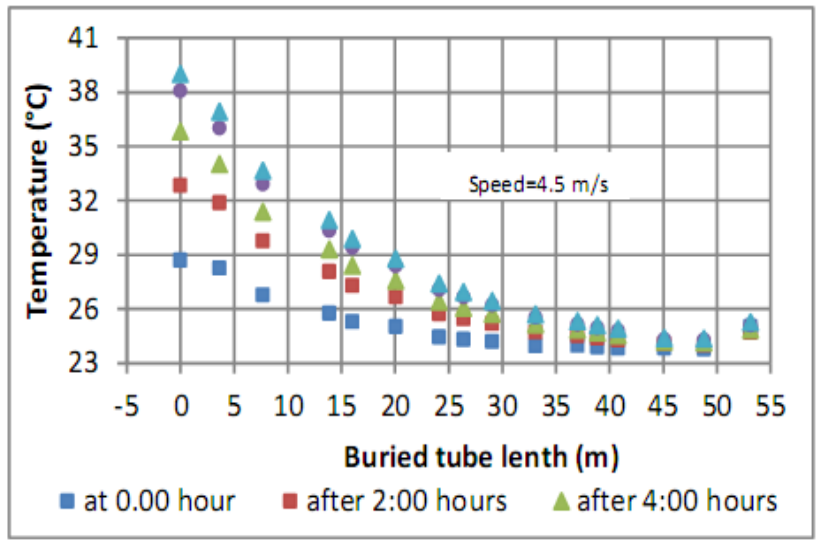

Figure 8. Tube length extent reducing air temperature

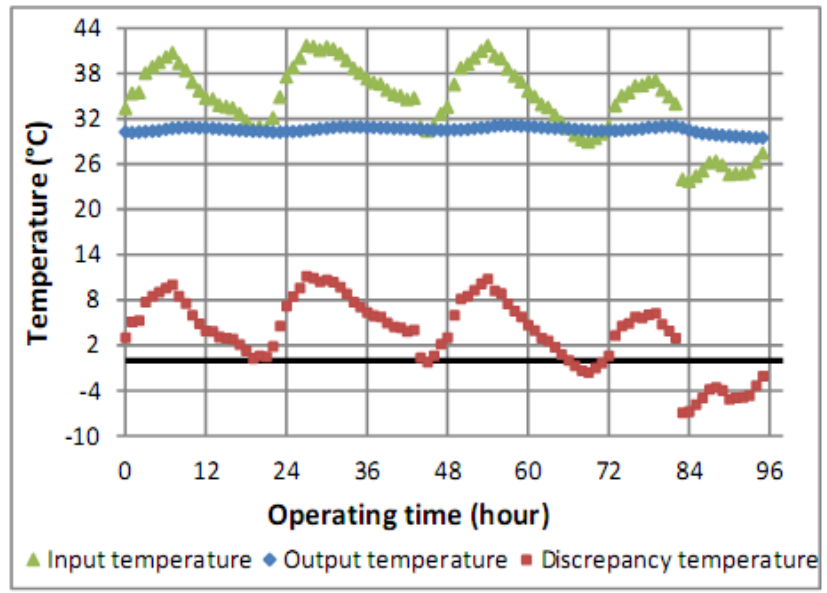

Figure 9. Heat exchanger inlet and outlet temperature and the variation of the difference between these two temperatures with operating time during September

The cooling potential of the EAHE which can be described by the air temperature difference between the inlet and the outlet of the exchanger is of major importance. This is a 
parameter that depends largely on the cooling potential of the soil, may determine the usefulness of the exchanger. The cooling potential of EAHE and the soil are shown in Figure 10 during the test.

It is clear that the study site (Biskra) has good cooling potential that encourages to use, in the future, the EAHE system to refresh buildings. This is cost-effective as the electricity consumption will be reduced and also it helps maintaining a safe environment with regard to the reduction of $\mathrm{CO}_{2}$ released during the production of electricity.

The curve of Figure 11 represents the linear variation of EAHE cooling potential with soil cooling potential. It shows the important influence of the cooling potential of the ground on the cooling potential of the exchanger. Similar result was foundby J. Vaz et al. [23] in their experimental study.

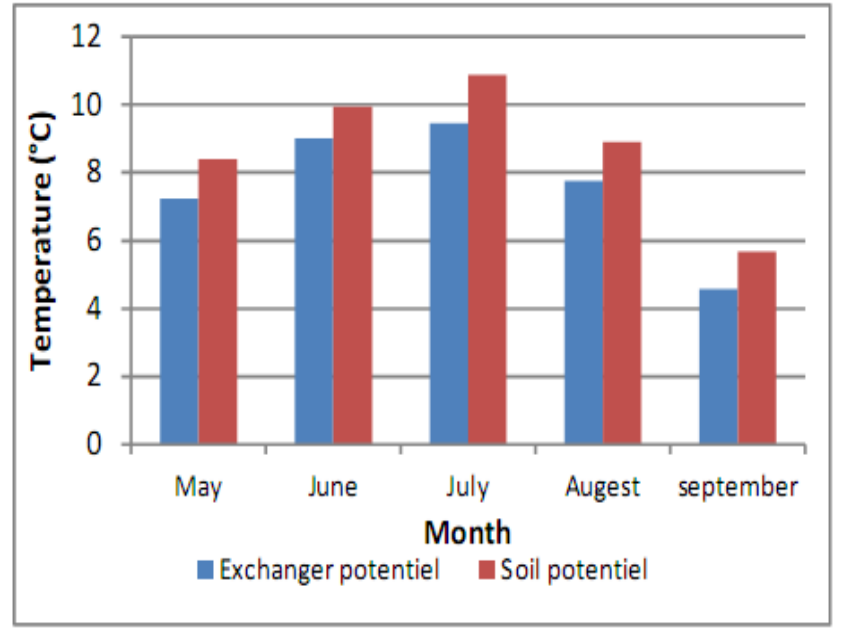

Figure 10. Exchanger and soil cooling means potential during the test period

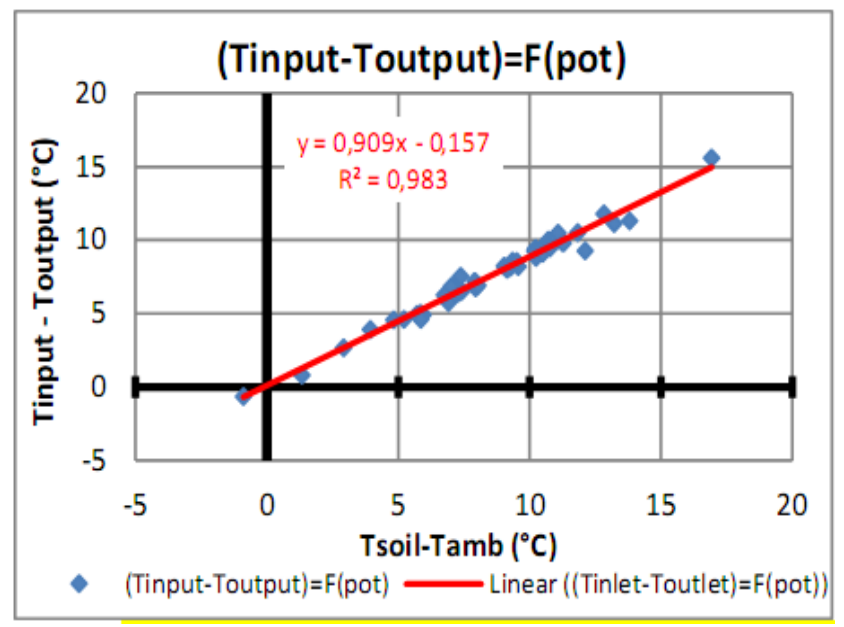

Figure 11. Variation of EAHE cooling means potential with soil cooling means potential during the test period

If a house of $100\left[\mathrm{~m}^{2}\right]$ area is inhabited by 5 people. This house is equipped with air renewal ventilation of $100\left[\mathrm{~m}^{3} /\right.$ hour] volume flow rate. During the cool season, the amount of heat brought by this aeration is given by the equation:

$\mathrm{Q}=\rho \cdot c \cdot v \cdot \Delta \mathrm{T}$ with:

$\rho:$ air density $=1.2\left[\mathrm{Kg} / \mathrm{m}^{3}\right]$

c: air heat capacity, $=1000[\mathrm{j} / \mathrm{Kg} . \mathrm{K}]$

v́: air volume flow rate, $=100\left[\mathrm{~m}^{3} / \mathrm{h}\right]$
$\Delta \mathrm{T}$ : the temperature difference between inside and outside the house.

If air flows into the buried pipe before entering in the house, the device decreases air thermal energy by:

$\mathrm{Q}=\rho \cdot \mathrm{c} \cdot v \cdot \Delta$ Tex; where $\Delta T e x$ is the temperature difference of the air at the inlet and outlet of the EAHE, $\Delta$ Tex $\approx 8[\mathrm{~K}]$. $\mathrm{Q}=266.67[\mathrm{~W}]$

The electrical power economized during cool period, 3.8 months, will be about $872.67[\mathrm{KWh} /$ year] if an $85 \%$ efficiency conventional air conditioner was used. It is about 3500 Algerian dinars/year i.e. $10-12 \%$. The reduction in $\mathrm{CO}_{2}$ equivalent will be $2.18 \mathrm{KgCO}_{2}$ eq.

The quality of the ventilation air must be controlled by one of the methods known in this field [24-25], subjecting the various constituents of our system to a periodic maintenance.

\section{CONCLUSIONS}

In this work, an experimental study on air-ground heat exchanger located at the precincts of the University of Biskra is presented. The average ambient temperature in the city of Biskra is around $40{ }^{\circ} \mathrm{C}$ during the summer period. The results obtained indicate that this technique is promising and can be used for cooling of residential and office buildings.

$\square$ The soil temperature during the summer varies between $22{ }^{\circ} \mathrm{C}$ by the end of April and $30^{\circ} \mathrm{C}$ in early September.

$\square$ The air temperature at the outlet of the exchanger is about $24{ }^{\circ} \mathrm{C}$ at the beginning of May to reach about $32^{\circ} \mathrm{C}$ in early September

A good difference between the ambient temperature and that of the air at the outlet of the EAHE is recorded. It reached a maximum value of $18^{\circ} \mathrm{C}$.

$\square \quad$ The influence of the tube length buried on the outlet temperature is up to $35 \mathrm{~m}$ remarkable surroundings. Beyond this length, the increase in length has a very slight influence.

$\square$ The EAHE 96 hours work without stopping does not affect its performance.

$\square$ The EAHE cooling potential is very good; it can exceed $15{ }^{\circ} \mathrm{C}$ in very hot days.

$\square$ The use of the EAHE is very useful to refresh during the spring and early summer. But towards the end of the summer, the outlet temperature of the heat exchanger is of the order of $30-31{ }^{\circ} \mathrm{C}$, in this case, our exchanger can be used for precooling prior to using conventional air conditioning. Such asolution that will participate in reducing power consumption.

$\square$ The results presented in this work are based on site experimental measurements and recordings in Biskra and may be used as a database for researchers for future studies.

\section{ACKNOWLEDGMENT}

We thank all members of the laboratory L.G.M. of the mechanical engineering department at the University of Biskra, Algeria who helped us carry out this work

\section{REFERENCES}

[1] Bouhess H, Hamdi H, Benhamou B, Bennouna A, Hollmuller P, Limam K. (2013). Dynamic simulation of an earth-to-air heat exchanger connected to a villa type 
house in Marrakech. 13th Conference of International Building Performance Simulation Association, Chambéry, France.

[2] Florides G, Kalogirou S. (2007). Ground heat exchangers - A review of systems, models and applications. Renewable Energy 32: 2461-2478. https://doi.org/10.1016/j.renene.2006.12.014

[3] Peretti C, Zarrella A, De Carli M, Zecchin R. (2013). The design and environmental evaluation of earth-to-air heat exchangers (EAHE). A literature review. Renewable and Sustainable Energy Reviews 28: 107116. https://doi.org/10.1016/j.rser.2013.07.057

[4] Ozgener L. (2011). A review on the experimental and analytical analysis of earth to air heat exchanger (EAHE) systems in Turkey. Renewable and Sustainable Energy Reviews 15: 4483-4490. https://doi.org/10.1016/j.rser.2011.07.103

[5] Thiers S. (2008). Bilans énergétiques et environnementaux de batiments à énergie positive. Thesis in L'Ecole Nationale Supérieure des Mines. Paris, pp. 255.

[6] Al-Ajmi F, Loveday D, Hanby VI. (2006). The cooling potential of earth-air heat exchangers for domestic buildings in a desert climate. Building and Environment 41: $235-244$

https://doi.org/10.1016/j.buildenv.2005.01.027

[7] Bansal V, Misra R, Agrawal GD, Mathur J. (2010). Performance analysis of earth-pipe-air heat exchanger for summer cooling. Energy and Buildings 42: 645-648. https://doi.org/10.1016/j.enbuild.2009.11.001

[8] Bansal V, Mishra R, Agarwal GD, MathurJ. (2012). Performance analysis of integrated earth-air-tunnelevaporative cooling system in hot and dry climate. Energy and Buildings 47: 525-532. https://doi.org/10.1016/j.enbuild.2011.12.024rg

[9] Alghannam A. R. O. (2012). Investigations of performance of earth tube heat exchanger of sandy soil in hot arid climate. Journal of Applied Sciences Research 8: 3044-3052.

[10] Misra R, Bansal V, Agrawal GD, Mathur J, Aseri T. (2013). Transient analysis based determination of derating factor for earth air tunnel heat exchanger in winter. Energy and Buildings 58: 76-85. https://doi.org/10.1016/j.enbuild.2012.12.002

[11] Moummi N, Benfatah H, Hatraf N, Moummi A, Ali SY. (2010). Le rafraîchissement par la géothermie: étude théorique et expérimentale dans le site de Biskra. Revue des Energies Renouvelables 13: 399-406.

[12] Dehina K, Mokhtari AM. (2012). Simulation numérique d'un échangeur air-sol-eau à co-courant. XXXe Rencontres AUGC-IBPSA, Chambéry, Savoie.

[13] Sehli A, Hasni A, Tamali M. (2012). The potential of earth-air heat exchangers for low energy cooling of buildings in South Algeria. Energy Procedia 18: 496506. https://doi.org/10.1016/j.egypro.2012.05.061

[14] Mebarki B, Draoui B, Abdessemed S, Keboucha A, Drici S, Sahli A. (2012). Etude d'un système de climatisation intégrant un puits canadien dans les zones arides, cas de Béchar. Revue des Energies Renouveables 15: 465-478

[15] Benhammou M, Draoui B. (2012). Simulation et caractérisation d'un échangeur géothermique à air destiné au rafraîchissement des bâtiments fonctionnant

dans les conditions climatiques du sud de l'Algérie. Revue des Energies Renouvelables 15: 275-284.

[16] Belloufi Y, Brima A, Zerouali S, Atmani R, Aissaoui F, Rouag A, Moummi N. (2010). Numerical and experimental investigation on the transient behavior of an earth air heat exchanger in continuous operation mode. International Journal of Heat and Technology 35(2): 279-288. https://doi.org/10.18280/ijht.350208

[17] Rouag A, Benchabane A, Labed A, Belhadj K, Boultif N. (2016). Applicability of a solar adsorption cooling machine in semiarid regions: Proposal of supplementary cooler using earth-water heat exchanger. International Journal of Heat and Technology 34(2): 281-286. https://doi.org/10.18280/ijht.340218

[18] Saadeddine M. (2014). Identification et analyse des principaux facteurs influant le comportement thermique d'un échangeur air/sol enterré. Thesis in Département de Génie mécanique université de Biskra.

[19] Mihalakakou G. (2002). On estimating soil surface temperature profiles. Energy and Buildings 34: 251-259. https://doi.org/10.1016/S0378-7788(01)00089-5

[20] Ozgener O, Ozgener L, Tester JW. (2013). A practical approach to predict soil temperature variations for geothermal (ground) heat exchangers applications. Heat and Mass Transfer 62: 473-480. https://doi.org/10.1016/j.ijheatmasstransfer.2013.03.031

[21] Benhammou M, Draoui B. (2011). Modélisation de la température en profondeur du sol pour la région d'Adrar - Effet de la nature du sol. Revue des Energies Renouvelables14: 219-228.

[22] Hollmuller P, Lachal B. (2014). Air-soil heat exchangers for heating and cooling of buildings: Design guidelines, potentials and constraints, system integration and global energy balance. Applied Energy 119: 476-487. https://doi.org/10.1016/j.apenergy.2014.01.042

[23] Vaz J, Sattler MA, Brum RDS, dos Santos ED, Isoldi LRA. (2014). An experimental study on the use of Earth-Air Heat Exchangers (EAHE). Energy and Buildings 72: 122-131. https://doi.org/10.1016/j.enbuild.2013.12.009

[24] Sofia D, Giuliano A. (2018). Air quality monitoring network for tracking pollutants: The case study of Salerno City center. Chemical Engineering Transactions 68: 67-72. https://doi.org/10.3303/CET1868012

[25] Nazira A, Zainal A. (2017). Graphical user interface application in matlab environment for water and air quality process monitoring. Chemical Engineering Transactions 56 : https://doi.org/10.3303/CET1756017

\section{NOMENCLATURE}

a

c

$\mathrm{H}$

$\mathrm{P}$

$\mathrm{R}$

$\mathrm{T}$

$\mathrm{V}$

v́ thermal diffusivity, $\mathrm{m}^{2} . \mathrm{s}^{-1}$ specific heat, $\mathrm{J}_{\mathrm{kg}^{-1}} \cdot \mathrm{K}^{-1}$ relative humidity, $\%$ probe solar radiation, w. m- ${ }^{2}$ temperature, $\mathrm{K}$

speed, m. s- ${ }^{1}$ air volume flow rate, $\mathrm{m}^{3} . \mathrm{h}$ 


\section{Greek symbols}

$\begin{array}{ll}\Delta & \text { difference of } \\ \delta & \text { Penetration depth,m } \\ \rho & \text { air density, kg.m }{ }^{3} \\ \lambda & \text { Thermal conductivity, w. m. K }\end{array}$

\section{Subscripts}

$\begin{array}{ll}\text { av } & \text { averraged } \\ \text { ex } & \text { exchanger }\end{array}$

\section{Abbreviations}

EAHE earth to air heat exchanger 